\title{
Investigando a Herança Cultural- religiosa Brasileira: A dificuldade em instituir um estado plenamente laico
}

\author{
InVESTIGATING THE BraziLIAN RELIGIOUS- \\ CULTURAL HERITAGE: \\ THE DIFFICULTY OF ESTABLISHING A FULLY \\ SECULAR STATE
}

Ricardo Rotondano *

Resumo: Investigar e identificar a cultura religiosa predominante na população brasileira é essencial para o entendimento das escolhas sócio-jurídicas efetuadas no Brasil. Ao encontrar a origem do padrão cristão que circunda a grande maioria da população, torna-se possível compreender os institutos jurídicos baseados em tal crença. Não obstante, ainda que se compartilhe determinada religião pela imensa maioria do povo brasileiro, deve-se ponderar acerca dos direitos das minorias não cristãs que estão sendo violados. Somente um Estado laico proporciona o devido respeito à liberdade religiosa em sua plenitude.

Palavras-chave: Cristianismo. Laicidade. Liberdade Religiosa. Religião.

Abstract: Investigate and identify the predominant religious culture in the Brazilian population is essential to the understanding of socio-legal choices made in Brazil. To find the origin of the Christian pattern that surrounds the majority of the population, it becomes possible to understand the legal institutions based on such a belief. Nevertheless, even if they share certain religion by the vast majority of the Brazilian people, one must ponder the rights of Christian minorities not being violated. Only a secular state gives due respect to religious freedom in its fullness.

Keywords: Cristianity. Secularism. Religious Freedom. Religion.

* Pós-graduado em Direito Constitucional pela Universidade Gama Filho/RJ. Advogado. E$\mathrm{m} \quad \mathrm{a} \quad \mathrm{i} \quad \mathrm{l}$ : oliveirarotondano@uol.com.br 


\section{INTRODUÇÃO}

Durante muitos séculos, a religião dominou não somente o pensamento particular dos indivíduos em suas ações cotidianas, mas igualmente as políticas e roupagens do próprio Estado. Tempos antigos, em que os governantes eram idealizados como verdadeiros deuses, cuja palavra ela lei - justamente pelo seu caráter divino. Religião e Estado confundiam-se em um só corpo, de modo que qualquer indivíduo que contrariasse a seita eclesiástica adotada por determinada nação, era invariavelmente condenado à pena capital.

No entanto, a modernidade trouxe uma nova roupagem cultural-religiosa, ao desvincular os preceitos religiosos da função estatal. Este é o principal conceito acerca da chamada laicidade estatal (em inglês, secularism), pregando que os Estados editem seus atos e normas jurídicas governamentais a partir de fundamentações estritamente racionais e neutras, sem qualquer vinculação religiosa. Tal preceito visa, essencialmente, garantir as liberdades de crença e de religião por parte dos cidadãos. Se as políticas estatais são voltadas para determinadas religiões, as demais crenças estarão, por consequência, sendo violadas.

Editar normas jurídicas com base em critérios totalmente imparciais, isentos de influência religiosa, é tarefa árdua. A relação entre cultura e direito é evidente. Tal conclusão mostra-se ainda mais concreta na medida em que uma determinada religião é compartilhada pela absurda maioria da população de determinado Estado - como é o caso das religiões cristãs no Brasil e nos países ocidentais.

O inegável poder social da religião altera o panorama perceptivo da população de modo que os preceitos religiosos compartilhados por tal crença parecem ser, para os indivíduos, os únicos corretos e possíveis. Consequentemente, a legislação dos Estados nacionais é elaborada seguindo os padrões das respectivas ideologias religiosas compartilhadas pela maioria do povo, quase que naturalmente. É o caso dos países islâmicos, com a pena de morte por apedrejamento em casos de adultério - enquanto em nações ocidentais, sequer é considerado crime. Cite-se ainda a penalização da poligamia em Estados ocidentais - e a sua plena aceitação em territórios islâmico-orientais.

Não obstante a dificuldade da presente problemática, é preciso que se insista na tarefa de ponderar, de forma axiologicamente neutra, acerca dos instrumentos jurídicos que se está a construir. Esta é uma clara exigência do princípio da liberdade religiosa, corolário da laicidade estatal, que viola não 
somente os direitos das outras religiões, mas também daqueles que não professem religião alguma - os agnósticos e ateus, como principais exemplos e que por isso mesmo não devem submeter-se obrigatoriamente aos preceitos cristãos positivados pelo Estado.

Para tanto, incorreremos inicialmente em uma investigação históricocultural acerca dos padrões religiosos herdados pelo povo brasileiro dos seus colonizadores. Tal pesquisa é essencial para definir, com precisão, as características religiosas que permeiam a população brasileira - e sua possível intolerância à religiões estrangeiras. Adiante, realizaremos breve análise acerca dos valores ínsitos à temática da religiosidade no seio público e democrático.

\section{A FORMAÇÃO CULTURAL-RELIGIOSA BRASILEIRA}

A análise acerca da formação religiosa da população brasileira deve incorrer em uma investigação histórica sobre o surgimento da religião cristã. $O$ Cristianismo ganha o seu maior impulso global a partir da sua adoção oficial pelo Império Romano, no final do século IV. A vastidão territorial do Império Romano favoreceu - e muito - a disseminação dos ideais cristãos nas sociedades ocidentais e mundiais.

Esse novo modelo cristão, transmitido através dos séculos, acabou construindo o domínio da cultura ideológico-cultural cristã sobre a Europa ocidental, sendo esta a principal base de toda e qualquer instituição estatal. Nas palavras de Chaim Perelman (1996, p.314): “Desde a conversão de Constantino até o século XVII pelo menos, a religião era considerada, na Europa cristã, o fundamento ideológico e institucional do Estado, do qual eram excluídos aqueles que não professavam a religião estabelecida".

O paradigma europeu-cristão chega até as terras brasileiras por meio da colonização portuguesa. Em Portugal, como uma típica nação européia ocidental do século XVI, havia o predomínio inegável da cultural religiosa cristã. Natural, deste modo, que a Coroa portuguesa trouxesse até as terras do novo mundo toda a sua herança cultural - incluindo, logicamente, sua religiosidade. Explica Marlon Anderson de Oliveira (2008, p.9):

[...] o Brasil enquanto colônia da metrópole portuguesa nasce sob a proteção da santa cruz católica e ao mesmo tempo sob o domínio do vasto império ultramarino português. A religião dos descobridores foi trazida em suas caravelas para que as novas terras descobertas pudessem receber a bênção de Deus e sua infinita proteção. 
Esta é a mesma lição trazida pela historiadora carioca Mary Del Priore (2004, p.7). A professora relata que a história da Igreja católica, em terras brasileiras, é marcada pela "autoridade" e "dominação". Mary Del Priore relata que "a Igreja católica, enquanto instituição e religião oficial do Estado português, chegou ao Brasil em 1500 com Pedro Álvares Cabral e daqui não mais saiu”.

Tal fato se deve à "estreita ligação da Igreja com o Estado português na defesa de interesses comuns - religiosos, políticos e econômicos", como explica Del Priore (2004, p.7). Essa aliança fortalecia o Estado português, que recebia uma série de concessões e licenças da Igreja católica. Reflexamente, esse pacto acabou por "moldar a mentalidade através da qual se fez a catequese no Brasil", fazendo com que os colonos partilhassem fervorosamente os preceitos cristãos:

Foi com essa mentalidade que os portugueses instalaram no Brasil uma sociedade cristã. [...] Não importava se os indígenas já tinham sido convertidos ou não: as igrejas recém-construídas, as ermidas e os oratórios levantados, as cruzes fincadas marcavam o território português e a garantia do domínio sobre essas almas que tinham de ser trazidas, ainda que à força, para Deus (DEL PRIORE, 2004, p.9).

A doutrina cristã dos colonizadores portugueses não era, pura e simplesmente, uma característica cultural do povo lusitano. Mais do que isso, para a Coroa portuguesa, a religião era "um instrumento de suma importância para o projeto colonizador que veio a se desenvolver nas terras do novo mundo português" (OLIVEIRA, 2008, p.9). Que importância tinha, afinal, a disseminação da cultura cristã entre os colonos?

Maria José Leite e Andréa Batista de Môra (2008, p.3) respondem à pergunta. Segundo as autoras, os padrões culturais do homem europeu se encontravam imbuídos de um significativo sentimento religioso, à época do século XVI. Ao desembarcarem em terras brasileiras, os colonizadores se depararam, de certa forma, com o caos - visto que o espaço social nativo continha características completamente divergentes de todo o paradigma português de "civilização". Era preciso, pois, reorganizar toda aquela estrutura do novo mundo, adaptando-a ao paradigma de vida da Europa ocidental.

O principal instrumento utilizado nessa missão de reorganização do espaço social da colônia foi a religião. Conforme Maria José Leite e Andréa Batista de Môra (2008, p.3), a religião foi claramente utilizada como "o suporte básico 
onde se assentou todo o projeto colonizador", justamente por ser "um objeto capaz de impor sua ordem a tudo o que estava em volta". Ainda segundo as autoras:

Por isso, a colonização e a implantação de um projeto católico de conversão foi elaborado com base nos padrões religiosos, morais e sociais europeus, pois a tentativa de destruição dos referenciais indígenas se soma à busca pela reprodução dos padrões sociais praticados na Europa.

Se por um lado, era interessante para a Coroa portuguesa disseminar a prática cristã sobre o novo mundo, reestruturando todo o espaço social nativo, para a Igreja Católica esta também era uma necessidade iminente. Após a Reforma Protestante - movimento reformista cristão originado no início do século XVI - a Igreja Católica vinha perdendo espaço e poder. Iniciou-se, desse modo, a Contra-Reforma, que na América "teve a perspectiva de conversão e de conquistar novas almas para rebanho católico que na Europa estava ceifado pelo protestantismo":

O projeto católico colocado em prática na América portuguesa pelos jesuítas e assenta no pensamento religioso, cultural e social do velho mundo na medida em que busca reproduzir seu universo cultural nessas terras. Naquela época viver fora do seio da religião era impensável, povoar o novo mundo não era visto apenas com uma missão do português mas da cristandade, pois era preciso catequizar os povos habitantes das novas terras (LEITE; MÔRA, 2008, p.3).

O projeto de colonização português não visava somente a disseminação da seita cristã, mas a destruição de qualquer outro referencial religioso existente em terras brasileiras, seja ele indígena, escravocrata ou mesmo entre os portugueses. A Igreja católica instituiu os seus preceitos eclesiásticos com voracidade e autoridade, pregando um modelo de intolerância com as demais culturas religiosas que, até os dias atuais, o povo brasileiro carrega como herança, conforme aduz Maria Betania de Melo Ávila (apud BATISTA; MAIA, 2006, p.17):

No caso do Brasil, a igreja católica é uma das instituições que contribuiu para a formação de uma sociedade hierárquica, autoritária e intolerante com a liberdade de religião. A tentativa de destruição da diversidade religiosa é 
parte do projeto de colonização. Aliás, um instrumento fundamental e dominação dos colonizadores sobre o povo nativo do continente foi a repressão a suas divindades e a imposição à conversão à Igreja Católica. A intolerância ao que é diverso, do ponto de vista religioso, é parte da nossa colonização e essa intolerância se estendeu ao campo da cultura como um todo, criando justamente um conflito entre as culturas dos diferentes povos e a cultura hegemônica do colonizador, totalmente apoiada na ordem religiosa como campo de legitimação do poder econômico e político. Dessa forma a igreja católica é parte do projeto colonial na América.

A argumentação exposta demonstra com clareza a construção do panorama cultural-religioso brasileiro, marcado pelos preceitos cristãos. A adoção de práticas sociais com tendência religiosa reflete, inegavelmente, na construção de institutos jurídicos com semelhante influência. Tal cenário exige profunda reflexão, para que - com enorme esforço - seja efetuada a coerente distinção entre as opções religiosas particulares e os regramentos jurídicos moralmente idôneos.

A referida missão visa, precipuamente, resguardar os direitos fundamentais dos cidadãos no que tange à plenitude do exercício da sua religiosidade. Sendo assim, somente a partir da desvinculação estatal de preceitos religiosos serão atendidos dois valores fundamentais: a laicidade estatal e a liberdade religiosa, dos quais trataremos com maior atenção nos capítulos subsequentes.

\section{EM BUSCA DA LAICIDADE ESTATAL NO BRASIL}

A religião é um fenômeno cultural de grande influência. O sociólogo francês Raymond Boudon (1995, p.467) aponta, com propriedade, que é plenamente possível demonstrar que a religião produz reflexos evidentes nas diversas ordens da atividade humana. Em especial, sobre a ordem política e a econômica. Ao presente estudo, interessa abordar a influência religiosa no campo político e jurídico brasileiro.

\subsection{O cenário político-religioso brasileiro}

Ainda hoje, é possível identificar uma clara aproximação entre o Direito brasileiro e a religião. Em especial, com o cristianismo, tendo em vista a herança 
cultural-religiosa legada pelos colonizadores. ${ }^{1}$ Podemos citar como exemplos desta afirmação a invocação do nome de Deus no preâmbulo constitucional, ${ }^{2}$ a presença de imagens sacras nos foros e prédios públicos, ${ }^{3} \mathrm{e}$ a inscrição "Deus seja louvado" estampada nas cédulas da moeda oficial brasileira. ${ }^{4}$

Nessa esteira, importante temática a ser abordada refere-se ao ensino religioso em escolas brasileiras. Seguindo um raciocínio imparcial e coerente, o conteúdo da referida disciplina deveria incluir temáticas referentes a questões históricas, culturais e políticas de diversas crenças - incorrendo em suas visões estético-morais acerca do homem e da sua espiritualidade. Dessa forma, "o ensino religioso em um estado laico tem toda a sua força, baseado em uma aproximação descritiva, analítica das religiões dentro de sua pluralidade", conforme explica Marília de Franceschi Neto Domingos (2008, p.164).

\footnotetext{
${ }^{1}$ Nem todos os temas que concernem à problemática "Religião e Estado" no Brasil são oriundos do cristianismo. Como exemplo, a questão acerca da utilização das cartas psicografadas como meio de prova. Sobre o espinhoso tema, necessário ressaltar os dois pontos de vista. Advogando contra a utilização das cartas psicografadas como meio de prova, Aldir Guedes Soriano (2007) enquadra o espiritismo como religião, concluindo desse modo não ser possível aplicar a referida hipótese, sob pena de restar ferido o preceito da laicidade estatal: "Isso [a utilização de cartas psicografadas como meio de prova] é no mínimo incoerente e incompatível com o princípio da separação entre a Igreja e o Estado. Qualquer outro tipo de prova baseada no conhecimento religiosos causaria a mesma estranheza. Também não se deveria admitir uma prova baseada na visão de um ministro do evangelho (profeta), por exemplo. Portanto, não se trata de uma questão de se tolerar ou não a crença espírita, evangélica, católica, ou seja ela qual for. [...] Cartas psicografadas não podem ser aceitas pelo direito sob pena de se retroceder na história. Concessões desse tipo revelam uma relação promíscua entre o direito e a religião tão censurável e execrável quanto o uso do púlpito como palanque eleitoral". Em sentido oposto, primando pela inovadora aceitação das cartas psicografadas como meio de prova, temos a lição do professor Flavio Tartuce. O jurista mineiro realiza ponderada reflexão sobre a natureza do espiritismo, elencando opiniões diversas que tentam enquadrá-la como ciência, religião ou mesmo filosofia. Abraçando os ensinamentos do codificador Allan Kardec, o professor Tartuce (2009) aceita a tese de que o espiritismo deve ser entendido como ciência, sendo este o principal fundamento para a aceitação das cartas psicografadas como meio de prova: "Não obstante tudo isso, pensemos que se deve considerar o espiritismo como ciência, e que todos os aplicadores do Direito relacionados com um determinado caso concreto pensam dessa forma. Além disso admitem a interdisciplinaridade [...]. Em outras palavras, admitem a intervenção de outras ciências na área jurídica. Ato contínuo, todos aqueles que decidem o caso concreto também acreditam nos princípios básicos e naquilo que prega a doutrina espírita. Nesse caso, haveria a possibilidade de se utilizar a prova psicografada na esfera cível? Aparentemente sim".

${ }^{2}$ Sobre o tema, relevante o estudo da ADIn $\mathrm{n}^{\circ}$ 2.076-5/AC, julgada pelo STF em 15 de agosto de 2002, sob relatoria do Min. Carlos Velloso: "Nesta ADIn, o Partido Social Liberal fundamentou sua ação argumentando que, quando a Constituição do Estado do Acre, em sua parte preambular, deixou de mencionar a expressão "sob a proteção de Deus", que deveria ser reproduzida tal como o fez a Constituição Federal, ofendeu o preâmbulo desta, visto que se trata de "ato normativo do supremo princípio básico com conteúdo programático e de absorção compulsória pelos Estados" (MACHADO; NETO, 2012). Na decisão do feito, o Min. Relator, Carlos Velloso, sustentou em seu voto que o preâmbulo constitucional não cria quaisquer direitos e deveres, nem sequer tem força normativa, somente refletindo a posição ideológica do constituinte: "Não se pode afirmar que esse preâmbulo está dispondo de forma contrária aos princípios consagrados na Constituição Federal. Ao contrário, enfatiza ele, por exemplo, os princípios democrático e da soberania popular. Só não invoca a
} 
Tal premissa, entretanto, foge à realidade, onde a disciplina Ensino Religioso limita-se a disseminar os preceitos cristãos entre os discentes. Jacira Pereira e Miriam Nishimoto (2012, p.2987-2988), em pesquisa realizada para mapear a oferta do Ensino Religioso em escolas públicas municipais do Mato Grosso do Sul, constataram que tal proposta, ao invés de proporcionar ao alunado a reflexão acerca das mais diferentes concepções espirituais que coexistem socialmente, contribuem para o crescimento da homogeneização religiosa em torno dos ideais cristãos:

Dessa forma, dirigente e/ou profissionais da escola acabam por operar nesse campo como agentes que tendo esses valores dogmáticos encarnados, predispõem nas práticas educativas os valores religiosos de forma naturalizada e cuja gênese é encontrado nas estruturas de uma instituição maior. [...].

proteção de Deus. Essa invocação, todavia, posta no preâmbulo da Constituição Federal, reflete, simplesmente, um sentimento deísta e religioso, que não se encontra inscrito a Constituição, mesmo porque o Estado brasileiro é laico, consagrando a Constituição a liberdade de consciência e de crença (C.F., art. $5^{\circ}$ ), certo que ninguém será privado de direitos por motivo de crença religiosa ou de conviç̧ão filosófica ou política (C.F., art. $5^{\circ}$, VIII). A Constituição é de todos, não distinguindo entre deístas, agnósticos ou ateístas" (STF, ADIn n ${ }^{\circ}$ 2.076-5/AC, rel. Min. Carlos Velloso, j. 15.08.2002, DJ 08.08.2003, p. 10).

${ }^{3}$ Discorrendo sobre a laicidade estatal e as imagens sacras nos prédios públicos, Daniel Sottomaior (2009): "O Estado laico deve ser um arbítrio que garante a todos a liberdade religiosa plena. E, como todo bom árbitro, ele não pode se comprometer com nenhum lado, do contrário sua isenção estaria comprometida. O que seria do juiz de futebol que apitasse um jogo portando símbolos de qualquer time? Assim como o Estado, o árbitro não se antepõe a nenhum clube de futebol, e bem por isso ele não pode se associar a qualquer um deles. O Estado laico, da mesma maneira, não é contra símbolos religiosos, mas contra o uso de símbolos religiosos de maneira que eles comprometam a neutralidade desse Estado. [...] A presença de símbolos religiosos em repartições públicas deixa claro quem tem o poder de estabelecer os símbolos, e quem só resta aceitar os símbolos que não lhes dizem respeito. Os símbolos religiosos afirmam hoje, como afirmavam quinhentos anos atrás, quem está mandando, e quem deve obedecer. Eles apontam que a população brasileira está dividida entre aqueles que não suportam a ideia de ter seus símbolos particulares retirados do espaço público, e aqueles que nunca tiveram seus símbolos colocados. Só poderá haver reconciliação quando nos reconhecermos como iguais". Importante destacar, ainda, a recente decisão unânime do Conselho da Magistratura do Tribunal de Justiça do Rio Grande do Sul, optando por retirar crucifixos e demais símbolos dos espaços públicos dos prédios da Justiça estadual gaúcha. O relator da matéria, desembargador Cláudio Baldino Maciel, afirmou em seu voto que o julgamento feito em uma sala de tribunal sob um expressivo símbolo de uma igreja e de sua doutrina não parece a melhor forma de mostrar o estado-juiz equidistante dos valores em conflito (CONJUR, 2012).

${ }^{4}$ É patente a violação ao princípio da laicidade decorrente de tal inscrição, como afirma Túlio Vianna (2010). O autor considera que, por não incomodar a maioria da população, a referida violação "acaba sendo negligenciada em detrimento dos direitos constitucionais dos ateus, agnósticos e politeístas, que ainda não são bem representados no Brasil". O Ministério Público Federal, através do Procurador dos Direitos do Cidadão em São Paulo, Jefferson Aparecido Dias, questionou em certa oportunidade o Banco Central pela referida medida. Para o procurador, "é inadmissível que um Estado laico insista em imprimir o dinheiro que circula pelo país com uma frase religiosa" (FREITAS, 2012). 
Essa é uma situação agravante quando refletido sobre a diversidade de crenças e o vasto repertório religioso que configuram a realidade e a escola brasileira, uma vez que Setton chama a atenção acerca de a escola constituirse como um subespaço capaz de projetar sistemas simbólicos com linguagens específicas e engendradoras de um ethos organizado, apto a prescrições morais, geradora de condutas e determinados padrões de comportamento (PEREIRA; NISHIMOTO, 2012, p.2987-2988).

Não é por acaso que a socióloga Maria Lúcia Silveira (2006, p.20) afirma que "estamos muito longe de visualizar um Estado que seja, de fato, laico, democrático e republicano", tendo em vista que o Brasil "possui uma política de tradição autoritária e conservadora”. A arraigada visão cristã do povo brasileiro interfere diretamente em sua vida social e política. O corpo legislativo pátrio, da mesma forma, edita atos normativos sem realizar rigorosa ponderação acerca dos valores religiosos que se está a positivar, e sobre os possíveis prejudicados por tais medidas.

\subsection{O pleito em favor da laicidade estatal}

Apesar da histórica aproximação entre a Igreja e o Estado, a evolução da teoria política exige, deste último, a adoção de preceitos laicos, não devendo o poder público privilegiar qualquer forma de crença religiosa:

Estado Laico é aquele que não se confunde com determinada religião, não adota uma religião oficial, permite a mais ampla liberdade de crença, descrença e religião, com igualdade de direitos entre as diversas crenças e descrenças e no qual fundamentações religiosas não podem influir nos rumos políticos e jurídicos da nação (VECCHIATTI, 2008). ${ }^{5}$

Ciro W. Carneiro Alves (2009) ensina que um dos requisitos para a instituição de uma sociedade democrática é o caráter laico do Estado e a sua completa desvinculação das instituições religiosas. Somente dessa forma, segundo o autor, é possível garantir a supremacia do interesse comum sobre o particular, concedendo ao cidadão a plena liberdade de crença e de culto, que lhes são de direito:

\footnotetext{
${ }^{5}$ Lecionando sobre o tema, Jonh Rawls (2002, p. 230-231): "O Estado não pode favorecer nenhuma religião específica e não se pode vincular sanções ou incapacidades a nenhuma afiliação religiosa ou ausência dela. [...] Seu dever se limita a garantir as condições de igual liberdade religiosa e moral".
} 
Em resumo, para pensar em um Estado laico é preciso pensar mais profundamente no significado entre a ordem das igrejas e a sua dominação sobre a sociedade, e de como essa relação é remetida mediatamente para uma ordem de Estado, por meio do poder político (ÁVILA apud BATISTA; MAIA, 2006, p.18).

A conscientização da necessidade de instituir um Estado laico é fruto, principalmente, de um movimento de natureza política denominado laicização, que transferiu a religião de um status público para um patamar privado. Raymond Boudon (1995, p.476) afirma tratar-se, em suma, do processo fruto de diversas evoluções e revoluções, que substituiu regimes políticos hierocráticos por regimes democráticos.

O antropólogo Cesar A. Ranquetat Jr. (2008, p.63-64) utiliza o termo laicidade. Tal expressão deriva do termo laico, leigo, que exprimem uma oposição ao religioso. Para o autor, tal fenômeno político possui caráter negativo, restritivo, podendo ser compreendida como "a exclusão ou ausência da religião da esfera pública":

A laicidade implica a neutralidade do Estado em matéria religiosa. Esta neutralidade apresenta dois sentidos diferentes, o primeiro já destacado acima: exclusão da religião do Estado e da esfera pública. Pode-se falar, então, de neutralidade-exclusão. O segundo sentido refere-se à imparcialidade do Estado com respeito às religiões, o que resulta na necessidade do Estado em tratar com igualdade as religiões. Trata-se neste caso da neutralidadeimparcialidade (RANQUETAT JR., 2008, p.63-64).

O primeiro sentido é, pois, uma das características básicas do regime democrático: a distinção entre o público e o privado. O público tem como principal objetivo a consecução do interesse comum; todos os outros interesses são privados e particulares, sendo incumbência de cada cidadão procurar sua respectiva realização. Leciona Boudon (1995, p.476) que "os interesses religiosos são interesses privados, ainda que essenciais para alguns". É possível que todos os cidadãos sejam adeptos de uma mesma religião; tal situação, no entanto, "não passa de uma circunstância contingente".

O segundo sentido encontra fundamento no artigo 19, I, da Constituição Federal, que veda à União, aos Estados, ao Distrito Federal e aos Municípios estabelecer cultos religiosos ou igrejas, subvencioná-los, embaraçar o seu funcionamento ou manter relações de dependência ou aliança com estes ou seus representantes, sempre ressalvada a colaboração de interesse público. 
Desse modo, há a proibição constitucional ao Estado brasileiro de instituir privilégios a quaisquer espécies de seitas religiosas. Quanto à ressalva referente à colaboração de interesse público, há que haver uma cautela estatal especial, posto que as políticas públicas não devam sofrer interferências religiosas, nem servir aos seus propósitos:

A convivência livre, justa e solidária, por meio da tolerância às manifestações de diversidade é, sem dúvida, um direito fundamental em um estado de direito democrático. A questão central, portanto, os Estados laicos será o de como lidar a interferência dessas instituições no delineamento das políticas públicas de modo que possam acarretar algum tipo de constrangimento a outras pessoas que não professam aquela fé religiosa (VENTURA apud BATISTA; MAIA, 2006, p.15).

O advogado Paulo Roberto I. Vecchiatti (2008) aduz tratar-se de um princípio constitucional, qual seja, o princípio da laicidade estatal. Tal princípio exige essencialmente que o Estado: "I. não se confunda com nenhuma instituição religiosa; II. não institua nenhuma religião oficial; III. trate igualmente as diversas crenças e descrenças [...]; IV. não aceite fundamentações religiosas para definir os rumos políticos e jurídicos da nação".

A laicidade estatal guarda relação com outro processo social de grande relevância: a secularização. A secularização "se refere ao declínio da religião na sociedade moderna e a perda de sua influência e de seu papel central e integrador"; é, pois, "o enfraquecimento dos comportamentos e práticas religiosas" (RANQUETAT JR., 2008, p.69). ${ }^{6}$ Sendo assim, a laicidade enquadrase em uma dimensão sócio-política, de separação entre o Estado e a Igreja, enquanto a secularização está inserida em uma dimensão sócio-cultural, correspondendo a uma diminuição da importância social religiosa.

\section{A IMPORT ÂNCIA DA LIBERDADE RELIGIOSA}

Não se deve confundir a laicidade estatal com a liberdade religiosa; estes são dois conceitos muito próximos - e, por certo, complementares - mas que

\footnotetext{
${ }^{6}$ Esta também é a lição de Paulo Antonio de Menezes Albuquerque (apud FERREIRA; GUANABARA; JORGE, 2011, p. 142): "Desse modo, a religião busca reinterpretar a atuação do sagrado no mundo, atribuindo uma direção às obras e realizações divinas em meio às contradições e dicotomias existentes (teodiceia), enquanto o mundo moderno move-se em sentido contrário, rumo a uma secularização ou processo de "desencantamento"'.
} 
podem existir separadamente. Tal distinção é ilustrada pelo professor Ranquetat Jr. (2008, p.64): o autor cita o exemplo da Grã-Bretanha para explicar que é possível haver a liberdade de crença, ainda que o Estado não seja laico. Dessa forma, o Estado britânico permite o culto religioso em geral, adotando, porém, preceitos de determinada seita eclesiástica.

A liberdade religiosa encontra fulcro no artigo $5^{\circ}$, VI, da Constituição Federal, que prega ser inviolável a liberdade de crença, sendo assegurado o livre exercício dos cultos religiosos e garantida, na forma da lei, a proteção aos locais de liturgias. Isto significa que cada cidadão é livre para escolher a crença que melhor lhe aprouver, ou até mesmo não ter crença alguma, posto que o Estado Democrático de Direito exige a convivência pacífica com tais diferenças.

Conhecida como liberdade de pensamento, como liberdade de consciência e também como liberdade de crença, a liberdade religiosa encontra-se igualmente protegida pela Declaração Universal dos Direitos Humanos, em seu artigo 18. Sobre o tema, imprescindível recorrer à longa - porém primorosa - lição do filósofo político americano John Rawls (2002, p.233), transcrita a seguir:

O traço característico desses argumentos a favor da liberdade de consciência é que eles se baseiam unicamente numa concepção da justiça. A tolerância não se origina de necessidades práticas ou razões de Estado. A liberdade religiosa e moral decorre do princípio da liberdade igual; e supondo-se a prioridade desse princípio, a única razão para negar as liberdades iguais é a de evitar uma injustiça ou perda de liberdade ainda maior. Além disso, a argumentação não se apoia em nenhuma doutrina fillosófica ou metafísica específica. Não pressupõe que todas as verdades possam ser estabelecidas mediante opiniões aceitas pelo senso comum; nem sustenta que tudo seja, em algum sentido, uma construção lógica derivada do que se pode observar ou provar através da investigação científica racional. $\mathrm{O}$ apelo, na verdade, se dirige ao senso comum, mas está estruturado de tal maneira que pode tornar desnecessárias maiores presunções. Por outro lado, a defesa da liberdade também não implica ceticismo em relação à filosofia ou indiferença religiosa. Talvez se possam apresentar argumentos a favor da liberdade de consciência que tenham uma ou mais dessas doutrinas como premissas. Isso não é motivo de surpresa, já que argumentos diferentes podem levar à mesma conclusão. Mas não precisamos prosseguir nessa questão. A defesa da liberdade é no mínimo tão forte como o mais forte de seus argumentos; os fracos e falaciosos é melhor esquecê-los. Aqueles que gostariam de negar a liberdade de consciência não podem justificar sua posição pela condenação do 
ceticismo em relação à filosofia e da indiferença religiosa, nem pelo apelo aos interesses sociais e questões de Estado. A limitação da liberdade só se justifica quando for necessária para a própria liberdade, para impedir uma incursão contra a liberdade que seria ainda pior.

O direito fundamental à liberdade religiosa integra o rol de direitos humanos de primeira dimensão, sendo fruto da conquista histórica em favor dos direitos civis e políticos. É, pois, um direito localizado na esfera da liberdade negativa, isto é, que exige uma abstenção do Estado. José Afonso da Silva (2008, p. 248) entende que a liberdade religiosa compreende três esferas: a liberdade de crença, a liberdade de culto e a liberdade religiosa.

$\mathrm{Na}$ liberdade de crença, entra a liberdade de escolha da religião, a liberdade de aderir qualquer seita religiosa, o direito de mudar de religião, e igualmente a faculdade de não aderir religião alguma. Engloba, ainda, a liberdade de descrença, a liberdade de ser ateu e de exprimir o agnosticismo. No entanto, a liberdade de crença "não compreende a liberdade de embaraçar o livre exercício de qualquer religião, de qualquer crença, pois aqui também a liberdade de alguém vai até onde não prejudique a liberdade dos outros" (SILVA, 2008, p.249).

A liberdade de culto, por sua vez, compreende a liberdade de orar e a de praticar os atos próprios das manifestações exteriores em casa ou em público, bem como a de recebimento de contribuições para tanto. Por fim, a liberdade de organização religiosa corresponde à possibilidade de estabelecimento e organização das igrejas e suas relações com o Estado (SILVA, 2008, p.250).

Paulo Roberto I. Vecchiatti (2008) realiza singular questionamento, sobre a possibilidade de instituir fundamentações religiosas para pautar posições políticas e jurídicas da nação, baseando-se na vontade da maioria da população. A resposta a esta pergunta, entretanto, é negativa. Segundo Vecchiatti, mesmo a maioria está sujeita aos ditames constitucionais, posto que a Constituição é o documento político e jurídico supremo da nação, e restringe a todos, sem exceção - maioria e minoria. Desse modo:

[...] a liberdade religiosa é um direito criado em benefício das minorias, para resguardar seu direito à crença e descrença, razão pela qual o fato da maioria da população ser de determinada religião não justifica a adoção de postura tendente a privilegiar uma fé religiosa em detrimento de outras (VECCHIATTI, 2008). 
Sobre o tema, citemos a lição do filósofo e jurista Chaim Perelman (1996, p.315). Segundo o autor, é a própria razão que impõe a regra da liberdade religiosa, estendida no século XVIII à liberdade de consciência. Por sua vez, o pluralismo religioso tem como finalidade do direito a construção de uma ordem social que garanta aos membros da comunidade política uma coexistência pacífica, sejam quais forem as suas concepções religiosas. Perelman conclui que, em uma sociedade pluralista, deve haver um consenso para que se estabeleça uma tolerância recíproca entre as crenças, garantindo a liberdade de religião, e culminando na completa separação do Estado e da religião. Desse modo:

A democracia nasce e se desenvolve a partir da pluralidade de idéias e opiniões, e não da ausência delas. É direito e garantia fundamental a livre expressão do pensamento, inclusive para a adequada formação das políticas públicas. Pretender calar os vários segmentos religiosos do país não é apenas antidemocrático e inconstitucional, mas traduz comportamento revestido de profunda intolerância e prejudica gravemente a saudável convivência harmônica do todo social brasileiro (MARTINS, 2007).

O regime democrático é marcado pela pluralidade, produzindo uma diversidade de estilos culturais. É justamente a convivência harmônica e pacífica entre estes o principal marco da democracia. Boudon (1995, p.480) lucidamente aduz não existir qualquer perspectiva superior que permita uma única escolha racional entre tais estilos. Todos os estilos são legítimos, e igualmente as suas opiniões particulares: esta é a verdadeira natureza da democracia. Nas palavras do autor, "todos os estilos são verdadeiros, desde que sejam considerados em seu conjunto e que todos os cidadãos os reconheçam em seu conjunto como ortodoxia política".

Seguindo o recente movimento de separação entre a Igreja e o Estado, e garantindo-se a liberdade de religião para toda a população, as nações ocidentais acabam por romper - ainda que lentamente - com a tradição cristã obrigatória. O referido cenário culmina no chamado processo de descristianização do ocidente: ou seja, os preceitos cristãos, sejam eles culturais ou jurídico-estatais, entram em declínio. Conforme explica o sociólogo Raymond Boudon (1995, p.479):

A descristianização assim entendida é um fenômeno de pluralização religiosa. Sua raiz última é igualmente política e democrática. A partir do momento em 
que todos os interesses que não sejam os interesses comuns são remetidos para a esfera privada, todos eles passam a ser politicamente legítimos. Os atores sociais privados tornam-se os únicos juízes de suas opiniões, de seus gostos, de suas ambições, desde que não transgridam as regras do jogo.

O objetivo do presente trabalho não é por fim à cultura religiosa cristã: longe disso. Mas não é possível aceitar que o Estado brasileiro coloque-a em posição de superioridade em relação às demais religiões, ainda que esta seja a crença compartilhada pela grande maioria da população brasileira. A manutenção, o respeito e o incentivo à pluralidade de crenças exige inexoravelmente que o patamar ocupado atualmente pelo Cristianismo - como religião privilegiada pelo setor público pátrio, em suas mais diversas formas - seja definitivamente rompido.

\section{CONSIDERAÇÕES FINAIS}

O presente escrito visa evidenciar a árdua tarefa de desvinculação jurídico-estatal de preceitos religiosos. Como exposto, cada população exprime juridicamente suas convicções e preceitos culturais, normatizando os regramentos sociais que lhe foram transmitidos e assimilados através dos séculos. Não se pode compactuar com este panorama, tendo em vista que a adoção estatal de preceitos religiosos representa violação aos princípios da laicidade estatal e da liberdade religiosa.

O Brasil é o cenário em análise, não fugindo à regra acima. Tendo sido colonizado pelos portugueses, herdaram destes a cultura religiosa cristã. Desde as Ordenações Imperiais, o Brasil é regido juridicamente por normas cuja influência reside em preceitos cristãos. Há, por certo, um descaso populacional em identificar e modificar tal panorama; é conveniente manter o referido paradigma, posto que a grande maioria dos cidadãos brasileiros segue preceitos cristãos.

O alerta - ainda que tardio - deve ser efetuado. Torna-se incoerente, ante toda a argumentação exposta, coadunar com o atual cenário, privilegiando as religiões cristãs e - consequentemente - impondo certos preceitos às demais religiões - ou mesmo aqueles que não se inclinam à religião alguma. Investigar a fundamentação que embasa as normas jurídicas e políticas públicas brasileiras é essencial para identificar a presença de fatores religiosos que devem caber apenas à esfera privada do cidadão. É preciso retirar os entraves existentes à plenitude das crenças não cristãs, garantindo-se desse modo o livre exercício da liberdade de crença e descrença no território brasileiro. 


\section{REFERÊNCIAS}

ALVES, Ciro Winston Carneiro. Brasil, um estado laico de direito? In:V ENCONTRO DE INICIAÇÃO CIENTÍFICA DA FACULDADE, 5., 2009, Fortaleza. Disponível em: $<$ http://www.fa7.edu.br/recursos/imagens/File/ direito/ic/v_encontro/brasilumestado.pdf>. Acesso em: 3 dez. 2011.

BATISTA, Carla; MAIA, Mônica (Org.). Estado laico e liberdades democráticas. Recife: Articulação de Mulheres Brasileiras/ Rede Nacional Feminista de Saúde/ SOS Corpo, 2006.

BOUDON, Raymond (Org.). Tratado de sociologia. Tradução de Teresa Curvelo. Rio de Janeiro: Jorge Zahar, 1995.

CONJUR. Justiça gaúcha vai retirar crucifixos de seus prédios. Revista Consultor Jurídico, 7 mar. 2012. Disponível em: $<$ http://www.conjur.com.br/ 2012-mar-07/tj-rs-manda-retirar-crucifixos-foros-predios-justica-gaucha>. Acesso em: 23 maio 2012.

DEL PRIORE, Mary. Religião e religiosidade no Brasil colonial. 6. ed. São Paulo: Ática, 2004.

DOMINGOS, Marília de Franceschi Neto. Escola e laicidade: o modelo francês. Revista Interações - Cultura e Comunidade, v.3, n.4, p.153-170, 2008 .

FERREIRA, Lier Pires; GUANABARA, Ricardo; JORGE, Vladimyr Lombardo (Org.). Curso de sociologia jurídica. Rio de Janeiro: Elsevier, 2011.

FREITAS, Jorge. MP encara polêmica sobre inscrição "Deus seja louvado" nas cédulas de real. Correio Braziliense, Brasília, 15 fev. 2012.

LEITE, Maria José; MÔRA, Andréa Batista de. A influência do imaginário europeu na construção do projeto católico português e a resistência indígena à sua implantação no Brasil colônia. Mneme - Revista de Humanidades (UFRN). Caicó, v. 9, n. 24, set/out., 2008. 
MACHADO, Vitor Gonçalves; NETO, Pedro Machado Ribeiro. "Justiça de Deus": terreno infértil do direito (?). Jus Navigandi, Teresina, ano 17, n. 3171, mar. 2012. Disponível em:<http://jus.com.br/revista/texto/21236/>. Acesso em: 17 mar. 2012.

MARTINS, Ives Gandra da Silva. Estado laico não é Estado ateu e pagão. Jus Navigandi, Teresina, ano 12, n. 1488, 29 jul. 2007. Disponível em: $<$ http://jus.com.br/revista/texto/10209/>. Acesso em: 4 dez. 2011.

OLIVEIRA, Marlon Anderson de. Entre a coroa e a cruz: a igreja colonial sob a égide do padroado. Mneme - Revista de Humanidades (UFRN). Caicó, v. 9, n. 24, set/out., 2008.

PEREIRA, Jacira H. V.; NISHIMOTO, Miriam M. Ameaças ao estado laico: ensino religioso em escolas públicas municipais de Mato Grosso do Sul. In: ENCONTRO NACIONAL DE DIDÁTICAS E PRÁTICAS DE ENSINO, Endipe, 16., 2012,. Campinas. Livro 1... Campinas: Junqueira \& Marin Editores, 2012.

PERELMAN, Chaim. Ética e direito. Tradução de Maria Ermantina Galvão. São Paulo: Martins Fontes, 1996.

RANQUETAT JR., César A. Laicidade, laicismo e secularização: definindo e esclarecendo conceitos. Tempo da Ciência, Toledo, v. 15, n. 30, 2.sem. 2008.

RAWLS, John. Uma teoria da justiça. Tradução de Almiro Pisetta e Lenita Maria Rímoli Esteves. 2. Ed. São Paulo: Martins Fontes, 2002.

SILVA, José Afonso da. Curso de direito constitucional positivo. 30. ed. São Paulo: Malheiros, 2008.

SILVEIRA, Maria Lúcia. A luta pelo direito ao aborto: um caso emblemático. In: BATISTA, Carla; MAIA, Mônica (Org.). Estado laico e liberdades democráticas. Recife: Articulação de Mulheres Brasileiras/ Rede Nacional Feminista de Saúde/ SOS Corpo - Instituto Feminista para a Democracia, abr. 2006. p.20-24. 
SORIANO, Aldir Guedes. Cartas psicografadas como meio de prova no processo penal. Jus Navigandi, Teresina, ano 12, n.1435, 6 jun. 2007. Disponível em: $<$ http://jus.com.br/revista/texto/9983/>. Acesso em: 17 mar. 2012.

SOTTOMAIOR, Daniel. O Estado verdadeiramente laico e a retirada de símbolos religiosos de repartição pública. Jus Navigandi, Teresina, ano 14, n. 2260, 8 set. 2009. Disponível em: <http://jus.com.br/revista/texto/13465/>. Acesso em: 17 mar. 2012.

TARTUCE, Flávio. Breves considerações quanto à utilização da prova psicografada no juízo cível. Conteúdo Jurídico, Brasília, 1 jan. 2009. Disponível em: <http://www.conteudojuridico.com.br/ ?artigos\&ver=2.22625>. Acesso em: 17 mar. 2012.

VECCHIATTI, Paulo Roberto Iotti. Tomemos a sério o princípio do estado laico. Jus Navigandi, Teresina, ano 13, n. 1830, 5 jul. 2008.

VIANNA, Túlio. Efetivar o Estado laico. Revista Fórum. Disponível em: $<$ http://tuliovianna.org/2010/12/21/efetivar-o-estado-laico/>. Acesso em: 23 maio 2012.

Recebido em: 2013-06-24 Aprovado para publicação: 2013-08-14

Como citar: ROTONDANO, Ricardo. Investigando a herança cultural-religiosa brasileira: a dificuldade em instituir um Estado plenamente laico. Revista do Direito Público, Londrina, v.8, n.2, p.221-238, mai/ago.2013. DOI: 10.5433/1980511X.2013v8n2p221. 